\title{
FORBIDDEN SUBSTANCES AND THE SPORTING LIFE: NO CONTEST
}

\author{
By Bernard Dixon
}

$\mathrm{T}$ he editor of Bio/Technology is a sportsman of some stature. [Dr. Dixon surely means girth.-Ed.] Your columnist's athletic record, by contrast, is at best patchy. It began when I selected long-distance running as a soft option at school (you went home early). It flourished for a few years on realising that I was rather good at this lonesome pursuit, was interrupted by academic diversions, and then both recommenced and expired during the jogging pandemic of 1970: Competing madly with the clock only a few weeks after resuming running following a decade of inactivity, I leapt off a high grassy bank, wrenched my ankle badly and limped home in agony.

It is with due temerity this month, therefore, that I venture an unfashionable speculation on a sporting theme. It welled up during the Barcelona Olympics two months ago, as it has on other big athletics occasions over the past 25 years. Now, with the emotion of those events spent, sober objectivity can perhaps be applied to the issue. My thesis is simply this. In origin, the Olympic ideal of free, fair, open competition between athletes, unsupported by artificial aids, was a noble one. Today, bioscience and biotechnology have made it wholly unrealistic. Regrettably, this means that the entire panoply of drug testing in the interests of equity in sport has become at best impracticable and at worst farcical.

My case rests on two principal arguments. First, there is the sheer impossibility of compiling sensible, consistent lists of forbidden substances. Even if we ignore the earliest Olympians' use of alcohol, hallucinogenic mushrooms and other natural products, proscription is discredited by a thousand anomalies. What is the point of banning caffeine in tablets but not in coffee? Should angina sufferers in shooting and archery contests be denied their beta-blockers, which can steady the arm? What about bronchodilator sprays, needed by asthmatics? And, as pharmacologist Joe Collier asked in the British Medical Journal (296:520, 1988) at the time of the Seoul Olympics, how on earth can we outlaw diuretics, used by boxers to lose weight quickly, and yet allow tennis players to take salt tablets to prevent electrolyte depletion in hot weather? What too, of modern scientific skills in matching nutrition with event and competition-particularly now that creatinine, extracted from meat, has been shown to boost athletic performance?

During the Barcelona games, such difficulties were symbolised by the shambles that occurred when two British weight lifters had to go home after showing positive (in samples taken several weeks earlier) for a prohibited substance, clenbuterol. Media coverage focussed initially on their "disgrace," but then shifted dramatically when the authorities announced that the pair might be returning. There was uncertainty as to whether the drug concerned had really been, or should have been, banned. Soon, expert was disagreeing with expert in an acrimonious public wrangle.
Eventually, the original verdict was sustained, but the whole fiasco clearly exposed one of the central flaws of drug testing in athletics.

Which brings us to point two. The millions of dollars worth of gas and liquid chomatograph/mass spectrometer equipment now being used to identify naughty athletes is technically impressive. Predictably, however, an equally powerful battery of scientific expertise is also being applied to help competitors to avoid the positive results that might otherwise show up during the testing of winners and randomly selected individuals. In addition, ranged against the scientists devising increasingly sensitive screening apparatus are pharmacologists and biotechnologists who are introducing novel substances that will not betray their presence. As described by B.J. Spalding in Bio/Technology (9:1050, 1991), erythropoietin and human growth hormone are two of the latest innovations. Meanwhile, other researchers are busily developing ways of smothering clandestine traces or ridding them from the body before testing.

All of this may appear to be a weird use of scientific expertise. But today virtually all international sport, including amateur sport, is really professional. Olympic gold medalists stand to gain vast sums as a result of their successes, their governments winning corresponding political prestige. It is simply unrealistic to believe that such handsome rewards will not feed back, in one way or another, into increasing sophistication in the sporting pharmacopoeia.

And there is another problem. Alongside drug testing, international athletics have long been marked by measures to exclude men from womens' events. Yet even screening based on amplification of the Sry gene, which has replaced the earlier, controversial chromosome test, is less than 100 percent reliable. More importantly, with the Human Genome Project, we stand on the brink of an era when it will be possible to take screening of this sort to a much finer level of resolution. Over the next decade, the relatively crude distinctions of today's cytogeneticists will be extended into genes and kilobases. We shall understand the molecular genetics underlying cardiopulmonary capacity, and know the identity of stretches of DNA concerned with the aerobic and anaerobic metabolism of muscle. Inevitably, analysis of this sort will show the clear advantages possessed by one individual over another. At this point, no doubt, committees and their scientific helpers will rush forward with even more ingenious tests to ensure that only equals compete with each other. They will be wasting their time.

It is with sadness, but conviction, that I suggest the Olympic ideal has had its day. Of course, coaches and team doctors have obligations to see that their charges do not take dangerous drugs, just as they advise them to sleep well, eat sensibly and not smoke. But using science to ensure fairness in sport? I really believe that we can forget it. 